\title{
Tracheoarterial Fistula
}

National Cancer Institute

\section{Source}

National Cancer Institute. Tracheoarterial Fistula. NCI Thesaurus. Code C127825.

An erosion through the tracheal wall into an artery. 